\title{
Tissue-resident T cells: dynamic players in skin immunity
}

\author{
Scott N. Mueller ${ }^{1,2}$, Ali Zaid ${ }^{1}$ and Francis R. Carbone ${ }^{1 *}$ \\ ' Department of Microbiology and Immunology, Peter Doherty Institute for Infection and Immunity, The University of Melbourne, Parkville, VIC, Australia \\ ${ }^{2}$ The ARC Centre of Excellence in Advanced Molecular Imaging, The University of Melbourne, Parkville, VIC, Australia
}

\section{Edited by:}

Kimberly Sue Schluns, University of Texas MD Anderson Cancer Center, USA

\section{Reviewed by:}

Wendy L. Havran, The Scripps Research Institute, USA

Bernhard Moser, Cardiff University, UK

Stephen Christopher Jameson, University of Minnesota, USA

\section{*Correspondence:}

Scott N. Mueller and Francis $R$.

Carbone, Department of Microbiology and Immunology, Peter Doherty

Institute for Infection and Immunity,

The University of Melbourne, 792

Elizabeth Street, Parkville, VIC 3010,

Australia

e-mail:smue@unimelb.edu.au;

fcarbone@unimelb.edu.au
The skin is a large and complex organ that acts as a critical barrier protecting the body from pathogens in the environment. Numerous heterogeneous populations of immune cells are found within skin, including some that remain resident and others that can enter and exit the skin as part of their migration program. Pathogen-specific $\mathrm{CD} 8^{+} \mathrm{T}$ cells that persist in the epidermis following infection are a unique population of memory cells with important roles in immune surveillance and protective responses to reinfection. How these tissue-resident memory $T$ cells form in the skin, the signals controlling their persistence and behavior, and the mechanisms by which they mediate local recall responses are just beginning to be elucidated. Here, we discuss recent progress in understanding the roles of these skin-resident $T$ cells and also highlight some of the key unanswered questions that need addressing.

Keywords: skin immunity, tissue-resident memory T cell, intravital imaging, two-photon microscopy, DETC, cell migration

\section{IMMUNE CELL SUBSETS IN SKIN}

The skin is a complex organ with critical roles in defense against pathogens. The epidermis forms a physical barrier that limits entry of microorganisms that make up the substantial microbiome on the skin (1), as well as pathogens and substances in the environment. The stratified layers of the epidermis are composed of specialized epithelial cells: the keratinocytes. The outermost layer of the epidermis, the stratum corneum, is composed of dead keratinocytes (corneocytes) that perform the main barrier functions. Keratinocytes in the basal layer of the epidermis are responsible for establishing the upper layers of the epidermis through cell division, and progeny of these cells migrate upwards as they differentiate and eventually die (2). Keratinocytes have key roles in immune defense via the production of cytokines, chemokines, and antimicrobial proteins in response to environmental or pathogenic stimuli. Cytokines and chemokines produced by keratinocytes alert cells in the dermis and in lymph nodes (LN) draining the skin of potential danger as well as recruit cells of the immune system (including neutrophils, monocytes, and $\mathrm{T}$ cells) to the skin.

The dermis is separated from the epidermis by a continuous basement membrane. The epidermis is interspersed with invaginations for hair follicles that are themselves, also lined by basement membrane and separated from the dermis. The dermis is composed of a network of fibroblasts that produce a collagen-rich extracellular matrix. In addition, blood vessels and lymphatic vessels are distributed throughout the dermis, facilitating entry of immune cells from the blood and exit to the LN, respectively.

A variety of immune cells are present in normal skin (Figure 1), including subsets of dendritic cells (DC) and lymphocytes, as well as macrophages, mast cells, and neutrophils (3). DC resident in the dermis can be divided into two main subsets: $\mathrm{CD}_{103^{+}} \mathrm{CD} 11 \mathrm{~b}^{-}$ (that can be further divided into langerin $+/-$ ) and $\mathrm{CD}_{11 \mathrm{~b}^{+}}$ (that can either be derived from steady-state precursors or from monocytes recruited during inflammation) (4). These DC migrate throughout the dermis before egressing via the afferent lymphatics to the LN where they either directly present antigen to T cells or transfer antigens to DC resident in the LN (5). In the epidermis, Langerhans cells (LC) form a dense network of DC capable of capturing antigen and migrating to the $\mathrm{LN}$ after traversing the basement membrane into the dermis. In mice, LC appear to be particularly efficient at tolerance induction and the formation of regulatory T cells (Tregs) $(6,7)$, whereas they are dispensable for induction of CD8 T cell responses to infections (8-10). Skin macrophages also populate the dermis and include perivascular macrophages that are distributed along post-capillary venules and can assist with the recruitment of neutrophils from the blood (11). Furthermore, a number of innate $\mathrm{CD}^{-}$lymphocytes (ILC) have been described in the skin, including NKp46 ${ }^{+}$ILC1 NK cells (12), CD90 ${ }^{\text {hi }}$ ILC2 cells that produce IL-13 (13), and more recently NKp44 ${ }^{+}$ILC3 cells in human skin with psoriatic lesions (14). These ILC appear to reside in the dermis where they can interact with resident cells such as mast cells (13).

Lymphocytes are present in significant numbers in healthy skin, in particular $\mathrm{CD}^{+} \mathrm{T}$ cells, which populate the dermis (15). In contrast, B cells are rare in healthy skin. Tregs are also found in substantial numbers in healthy mouse dermis and their contribution to immunity or inflammation appears regulated by skin commensals (16). Skin Tregs display a much slower migrational velocity compared with effector $\mathrm{CD} 4^{+} \mathrm{T}$ cells although acute inflammation results in a rapid increase in their motility (17). $\mathrm{CD}^{+} \mathrm{T}$ cells 


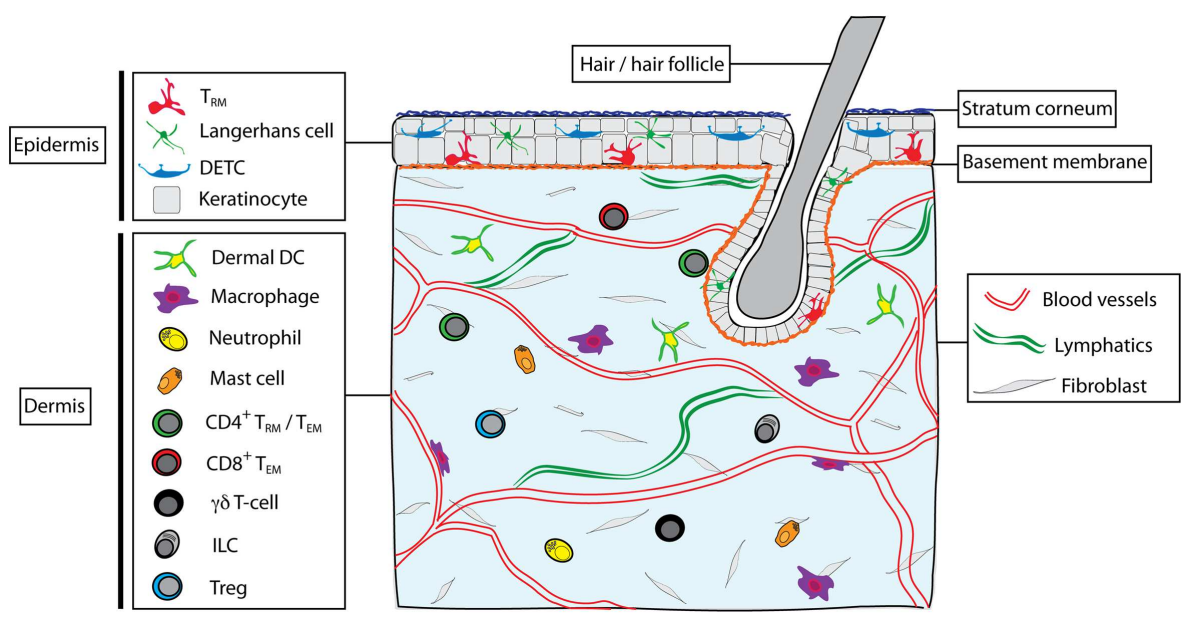

FIGURE 1 | Skin structure and immune cell types found in skin. The skin is composed of epidermis and dermis, interspersed with hair follicles. Dead keratinocytes construct the stratum corneum in the outer epidermis. The dermis and epidermis are separated by a basement membrane. Blood vessels and lymphatic vessels and a network of fibroblasts are found in the dermis, as well as nerves, sebaceous glands, sweat glands (not shown). Multiple immune cells types are found within skin, including Langerhans cells, dendritic epidermal $\gamma \delta T$ cells (DETC), and memory $\alpha \beta T$ cells $\left(T_{\mathrm{RM}}\right)$ in the epidermis. In the steady state, the dermis contains a heterogeneous mix of immune cells, including subsets of dendritic cells (including CD11 $b^{+}$and CD103+ DC), macrophages (including dermal and perivascular macrophages), neutrophils, mast cells, $\gamma \delta T$ cells, ILC, CD4 ${ }^{+} T$ cells (both $\mathrm{T}_{\mathrm{EM}}$ and possibly $\mathrm{T}_{\mathrm{RM}}$ subsets), $\mathrm{T}$ regulatory cells (Treg), and $\mathrm{CD} 8^{+} \mathrm{T}_{\mathrm{EM}}$. are found in the skin in mice and humans, and are predominantly localized to the epidermis, in contrast to the predominantly dermal $\mathrm{CD}^{+}{ }^{+} \mathrm{T}$ cells. This dichotomy is striking following herpes simplex virus infection (HSV) where antigen-specific $\mathrm{CD}^{+}$and $\mathrm{CD} 8^{+}$ memory $\mathrm{T}$ cells localized to the dermis and epidermis, respectively, after clearance of the pathogen (18) (Figure 2A). The epidermal $\mathrm{CD}^{+} \mathrm{T}$ cells persist for long periods in this anatomical compartment (19) and are now commonly referred to as tissue-resident memory $\mathrm{T}$ cells $\left(\mathrm{T}_{\mathrm{RM}}\right)$.

Finally, populations of $\gamma \delta \mathrm{T}$ cells are found in the dermis and epidermis, where they can contribute to wound healing and immune responses (20-22). Dendritic epidermal $\gamma \delta \mathrm{T}$ cells (DETC) form a prominent network in the skin in mice where they appear to monitor the integrity of the epidermal layer. DETC form polarized immunological synapses that anchor at keratinocyte tight junctions (23). In response to infection or wounding, DETC upregulate molecules including NKG2D, JAML, and CD100 that contribute to inflammation and assist in wound closure (21, 24-26). DETC can also be infected by viruses such as HSV-1, which may influence their survival and functions during skin infections (27).

\section{SKIN TISSUE-RESIDENT MEMORY T CELLS}

$\mathrm{CD}^{+} \mathrm{T}_{\mathrm{RM}}$ cells that reside within the epidermis are retained in this compartment for very long periods without reentering the circulation $(19,28)$. Populations of $\mathrm{T}_{\mathrm{RM}}$ have also been described in other tissues including the small intestine $(29,30)$, vaginal mucosa $(18,31)$, brain $(32,33)$, lung (34), salivary glands (35), and thymus (36). These cells can be identified by high expression of the $\alpha_{\mathrm{E}}$ integrin chain (CD103) and the marker CD69 (19). T cells expressing this canonical $\mathrm{T}_{\mathrm{RM}}$ phenotype have also been observed in other tissues such as the kidney, pancreas, and heart (32), while CD69+
T cells may also reside in LN and spleen for extended periods and provide a unique pool of cells that could guard against systemic pathogen entry (37).

Tissue-resident memory $\mathrm{T}$ cells that form in the skin, intestine, and lungs were recently shown to express a core set of genes that may facilitate accurate dissection of this memory $\mathrm{T}$ cell subset at a molecular level (38). This transcriptional signature suggests $\mathrm{T}_{\mathrm{RM}}$ undergo a similar developmental program in different tissues. Elucidating the molecular pathways critical for $\mathrm{T}_{\mathrm{RM}}$ development from tissue-derived signals will be important for future therapeutic approaches.

In addition to $\mathrm{CD}^{+} \mathrm{T}$ cells, some $\mathrm{CD} 4^{+} \mathrm{T}$ cells may also form a $\mathrm{T}_{\mathrm{RM}}$ population in the lungs after respiratory viral infection (39). Although a proportion of the memory $\mathrm{CD} 4^{+} \mathrm{T}$ cells found within the dermis appear to be capable of entering the circulation (18), it is not yet clear whether the remaining cells permanently or semipermanently reside in this site (i.e., could be designated $\mathrm{T}_{\mathrm{RM}}$ ) and might thus be distinguished from circulating $\mathrm{T}$ effector memory cells $\left(\mathrm{T}_{\mathrm{EM}}\right)$.

During infection or inflammation of the skin, effector $\mathrm{CD} 8^{+} \mathrm{T}$ cells enter the dermis from the blood, and can then be recruited into the epidermis. This process is dependent on chemokine receptor signals, including CXCR3 (38). Whether other chemokine receptors are also required for $\mathrm{CD}^{+} \mathrm{T}$ cell entry into the epidermis is unclear, though this is likely since $\mathrm{T}_{\mathrm{RM}}$ formation was only partially blocked when effector $\mathrm{CD} 8^{+} \mathrm{T}$ cells lacked CXCR3 expression. In contrast, in order to exit the skin via lymphatics $\mathrm{T}$ cells need to upregulate expression of CCR7, and blocking this step can promote increased $\mathrm{T}_{\mathrm{RM}}$ formation. $\mathrm{T}_{\mathrm{RM}}$ in skin develop from $\mathrm{KLRG}^{-}$effector cells that also give rise to classical central memory $\mathrm{T}$ cells $\left(\mathrm{T}_{\mathrm{CM}}\right)$ in the circulation (38). Once they enter the skin, these precursors migrate more effectively to CXCR3 ligands 
A
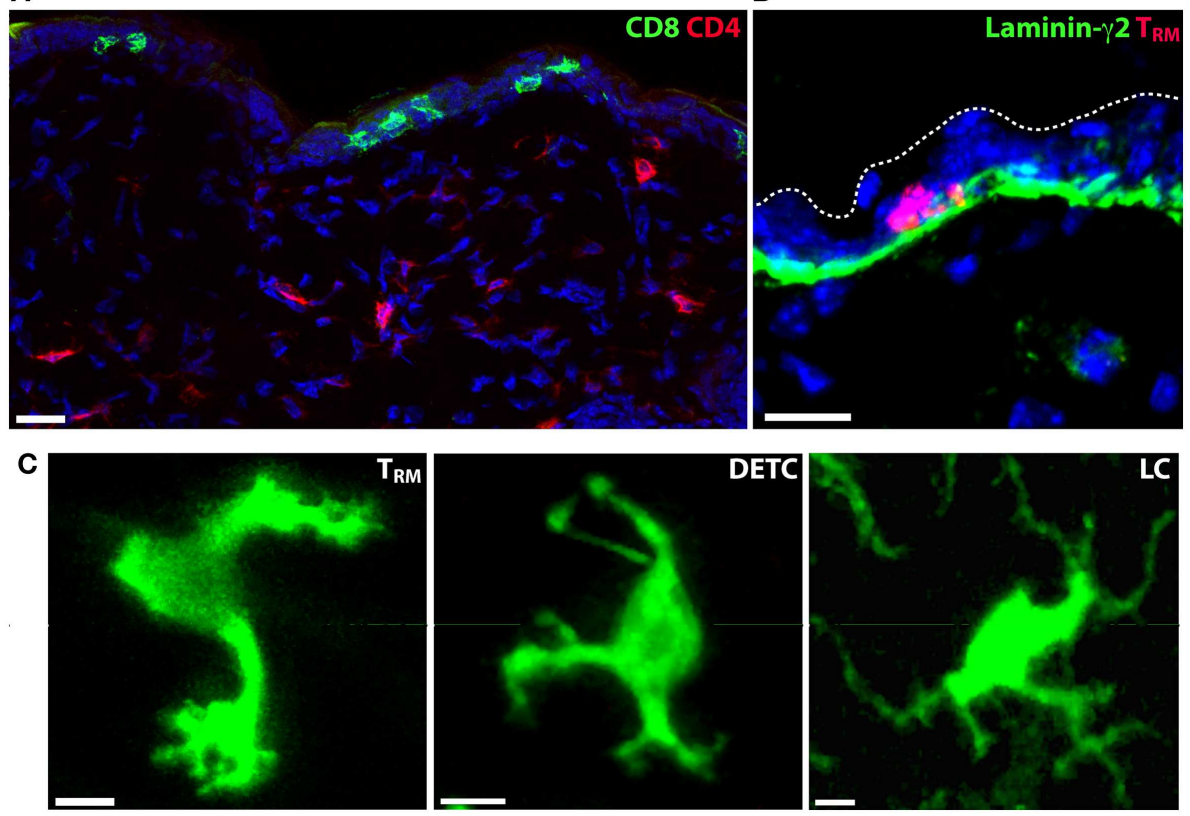

FIGURE 2 |Tissue-resident immune cells in the epidermis. (A) CD4 ${ }^{+}$and $\mathrm{CD}^{+} \mathrm{T}$ cell localization in the skin of mice following clearance of HSV-1 infection. CD4 ${ }^{+} \mathrm{T}$ cells (red) localize to the dermis, while $C D 8^{+} \mathrm{T}_{\mathrm{RM}}$ persist in the epidermis. Nuclei are stained blue with DAPI. (B) Skin $T_{R M}$ localize to the basal epidermis in contact with the basement membrane that separates dermis from epidermis. CD8 ${ }^{+} T_{\mathrm{RM}}$, red; laminin- $\gamma 2$, green; DAPI, blue. (C) The morphology of epidermis-resident $T_{R M}, L C$ and DETC is distinct. Scale bars: $A$, B: $20 \mu \mathrm{m} ; \mathrm{C}: 5 \mu \mathrm{m}$. including CXCL10. Signals found within the epidermis instruct $\mathrm{CD}^{+} \mathrm{T}$ cells to develop into $\mathrm{T}_{\mathrm{RM}}$ via upregulation of molecules involved in the persistence of these cells (CD103 and CD69), and downregulation of S1PR1 that is required for tissue egress (38, 40). Our recent data also revealed that $\mathrm{T}_{\mathrm{RM}}$ express high levels of regulator of G protein signaling-1 (RGS1) and RGS2 (38). RGS1 expression has been shown to reduce $\mathrm{T}$ cell migration in response to CXCL12 and CCL19 (41), suggesting that these molecules may also contribute to the migration and persistence of $\mathrm{T}_{\mathrm{RM}}$ within the skin as well as other tissues.

\section{MIGRATION BY SKIN TRM}

$\mathrm{CD}^{+} \mathrm{T}_{\mathrm{RM}}$ localize to the basal layers of the epidermis in mice and appear to be in regular contact with the basement membrane that separates the epidermis from the dermis (42) (Figure 2B). Whether $\mathrm{T}_{\mathrm{RM}}$ use this as a substrate for migration and adhesion is not known. Although the epidermal layer is considerably thinner in mice than in humans, $\mathrm{CD} 8^{+} \mathrm{T}$ cells also appear to localize to the border between the epidermis and the dermis in humans following HSV-2 infection (43) and in healthy or psoriatic skin (44). A unique feature of skin $\mathrm{T}_{\mathrm{RM}}$ is their highly dynamic dendritic morphology $(18,42,45)$ (Figure 2C). In contrast, T cells in the dermis consistently display a more amoeboid shape that is typical of $\mathrm{T}$ cells observed in all other tissues thus far. Whether $\mathrm{T}_{\mathrm{RM}}$ in other tissues display a similar morphology and slow mode of migration is yet to be determined.

The immediate tissue environment appears to dictate the morphology and locomotion of $\mathrm{T}$ cells. This is supported by our observations in mice that both $\mathrm{CD} 4^{+}$and $\mathrm{CD} 8^{+} \mathrm{T}$ cells displayed a pronounced dendritic morphology when present within the epidermis, irrespective of whether the T cells were activated effector cells or memory cells (42). In addition, epidermal LC and DETC both adopt dendritic shapes. Notably, each of these cells $\left(\mathrm{T}_{\mathrm{RM}}\right.$, DETC, and LC) can be distinguished from each other by key differences in cell shape (Figure 2C). Whereas $\mathrm{T}_{\mathrm{RM}}$ form many amorphous shapes marked by short dendrites and many small projections similar to filopodia, DETC produce a relatively consistent number of long dendrites and are mostly immotile because they are anchored in the upper epidermis. LC are immotile and produce multiple long, branched dendrites. While both DETC and LC project their dendrites upwards toward the stratum corneum, $\mathrm{T}_{\mathrm{RM}}$ were only observed to extend projections laterally (42).

T cells migrating within the epidermis reduce their speed upon resolution of inflammation (42), suggesting that tight connections between keratinocytes present a difficult environment for $\mathrm{T}$ cells to navigate. It will be important to determine whether $\mathrm{T}_{\mathrm{RM}}$ regulate unique molecules that facilitate digestion of the surrounding matrix and cell-cell adhesions to allow them to move relatively freely. The mechanisms used by $\mathrm{T}_{\mathrm{RM}}$ to navigate the epidermis, including the molecules and pathways regulating the actin cytoskeleton to induce the unique cell shape are unclear. Since T cells migrating within tissues do not typically generate substantial protrusions such as lamellipodia or blebs (46), the way in which the actomyosin network generates force to propel T cells in the epidermis may differ from that in the dermis and other tissues. Moreover, the roles of adhesion molecules such as integrins and chemotactic factors including chemokines in controlling $\mathrm{T}$ cell migration in the epidermis is not known. The integrin CD103 is involved in the 
attachment of DETC dendrites to the keratinocytes (23). We found that $\mathrm{CD} 103$ expression by $\mathrm{T}_{\mathrm{RM}}$ is important for their long-term retention in skin (38). This is unlikely to involve stable dendrite attachment due to the motile nature of $\mathrm{T}_{\mathrm{RM}}$, though persistent adhesion to the keratinocytes via E-cadherin may facilitate the retention of $\mathrm{T}_{\mathrm{RM}}$ in this site. $\mathrm{T}_{\mathrm{RM}}$ also show increased expression of E-cadherin, the ligand for integrin $\alpha_{\mathrm{E}} \beta_{7}$, as well as the integrin $\alpha_{1} \beta_{1}$ that binds collagen and laminin, both major components of the basement membrane separating epidermis from dermis. $\mathrm{T}_{\mathrm{RM}}$ in skin have increased expression of the chemokine receptor CCR8 compared with memory T cells in other tissues (38). Expression of CCR8 is programed by the epidermis (47) suggesting that expression of this receptor is important for $\alpha \beta T$ cell residence in this site. Together, these receptors potentially contribute to adhesion, morphology, and survival of $\mathrm{T}$ cells in the epidermis.

\section{IMMUNOSURVEILLANCE AND LOCAL PERSISTENCE OF SKIN TRM}

Although $\mathrm{T}_{\mathrm{RM}}$ localization in the skin can be relatively dispersed (28), they predominate at sites of infection or inflammation (19). This concentration of memory cells in mouse skin remains remarkably constant for $>1$ year after infection, despite their sustained motility (42). In silico simulation of the migration of $\mathrm{T}_{\mathrm{RM}}$ in the skin over long periods revealed that $\mathrm{T}_{\mathrm{RM}}$ move by random brownian motion and persist within the region of the epidermis in which they form simply as a result of this slow migration. These experiments suggest that $\mathrm{T}_{\mathrm{RM}}$ induced by infection or vaccination should persist for very long periods in the immediate environment where they were formed and provide robust sitespecific immunity. While such site-specific immunity may be of little use against subsequent infections at remote sites, repeated infections can induce $\mathrm{T}_{\mathrm{RM}}$ in non-involved regions of skin (28), potentially providing more widespread protection at least in this tissue. Whether this is the case with many infections or tissues and the protective efficacy of these more dispersed $T_{R M}$ needs to be investigated further.

Skin $\mathrm{T}_{\mathrm{RM}}$ display a persistent mode of random migration that can facilitate surveillance of skin against reinfection or the recrudescence of latent viruses such as $\operatorname{HSV}(42,45)$. Although $\mathrm{T}_{\mathrm{RM}}$ migrate considerably slower in the epidermis of mice than $\mathrm{T}$ cells in the dermis or in lymphoid tissues, the cells are trapped within the constrained epidermal environment and move largely twodimensionally. How $\mathrm{T}_{\mathrm{RM}}$ survey the epidermis in humans remains to be visualized, although the location of these cells in the basal epidermis in human skin samples suggests that the mechanism and efficiency of immunosurveillance may be very similar to that observed in mice. Importantly, in addition to the shape and motility of $\mathrm{T}_{\mathrm{RM}}$, the density of cells present in the epidermis will likely influence the efficiency of their surveillance, as suggested in experiments modeling $\mathrm{T}_{\mathrm{RM}}$ migration (45). Therefore, novel vaccine strategies designed to induce $\mathrm{T}_{\mathrm{RM}}$ in the skin or other sites in the body may need to reach a certain threshold of $\mathrm{T}_{\mathrm{RM}}$ density in the tissues for effective protection against disease.

\section{EPIDERMAL NICHE}

As mentioned above, large numbers of $\gamma \delta \mathrm{T}$ cells (DETC) exist in the epidermis in mice, where they contribute to homeostasis, would repair and inflammation. In humans, $\gamma \delta \mathrm{T}$ cells are present in the epidermis, though in lower numbers than $\alpha \beta T$ cells. The reason for this difference is unclear, though both $\mathrm{T}$ cell subtypes present in human epidermis can contribute to wound repair (21), suggesting that this may reflect a functional specialization of all $\mathrm{T}$ cells that persist in this tissue, as opposed to only $\gamma \delta \mathrm{T}$ cells. DETC are the first $\mathrm{T}$ cells that form in mice very early in life. After migrating to the skin, they persist for life and are maintained by homeostatic turnover. Examination of DETC in mouse skin after the clearance of HSV infection revealed a substantial and sustained decrease in DETC numbers around the site of infection, and a corresponding increase in numbers of virus-specific $T_{R M}$ (42). This inverse relationship between DETC and $\mathrm{T}_{\mathrm{RM}}$ was maintained for months, suggesting that DETC were unable to repopulate regions of skin containing considerable numbers of $T_{R M}$. These findings indicate the existence of a $\mathrm{T}$ cell-specific niche within the epidermis that regulates the total number of $\mathrm{T}$ cells in this site, irrespective of TCR usage or specificity. Both DETC and $\mathrm{T}_{\mathrm{RM}}$ rely upon the cytokine IL-15 and signals via the aryl hydrocarbon receptor (AhR) for persistence in the skin $(38,42,48,49)$. AhR is a transcription factor that can regulate a large number of genes, including c-kit and various cell cycle genes, suggesting that this pathway may influence $\mathrm{T}$ cell proliferation and homeostasis in the epidermis (50). Ligands for AhR are produced in the epidermis via metabolism of tryptophan or from microbiota such as yeast. Nevertheless, AhR ligands are abundant in the skin, suggesting that other mechanisms likely also contribute to the regulation of $\mathrm{T}$ cell numbers in the epidermis.

If the epidermis constitutes a privileged niche with limited space for populations of $\mathrm{T}$ cells, this may have implications for $\mathrm{T}_{\mathrm{RM}}$ persistence following subsequent infection or inflammation where new populations of effector $\mathrm{CD} 8^{+} \mathrm{T}$ cells are recruited to the skin. Therefore, whether there is a maximum number of $\mathrm{T}$ cells capable of persisting in the epidermal niche remains a key unanswered question. If so, we would expect that competition for space in this niche would restrict numbers of $\mathrm{T}_{\mathrm{RM}}$ that can persist in regions of skin prone to multiple infections. Moreover, if effective protection from infection requires a certain density of $\mathrm{T}_{\mathrm{RM}}$ in skin to rapidly respond, then competition for niche may influence such immunity. This also raises the intriguing question of whether low numbers of $\gamma \delta \mathrm{T}$ cells in the epidermis of adult humans, and correspondingly higher numbers of $\alpha \beta T$ cells is, at least in part, the result of replacement of DETC via competition for space by $T_{R M}$ that are generated by infections and environmental antigens. Developing a better understanding of the mechanisms of T cell homeostasis within the epidermis is critical for the design of strategies to boost immunity to infections as well as potentially reducing unwanted $\mathrm{T}$ cell responses.

\section{PROTECTION BY SKIN TRM}

Reinfection with a previously encountered pathogen results in recruitment of circulating memory $\mathrm{T}$ cells to the inflamed tissues where they function to eradicate the infection. $\mathrm{CD} 8^{+} \mathrm{T}$ cells recruited to tissues then clear the pathogen by killing infected cells and releasing cytokines. This process is still relatively slow, yet appears to be significantly enhanced by the presence of $T_{R M}$ within the infected tissues. Notably, $\mathrm{T}_{\mathrm{RM}}$ present within mucosal tissue 
epithelia were found to rapidly produce interferon- $\gamma$ upon peptide stimulation, resulting in the non-specific recruitment of circulating memory $\mathrm{T}$ cells into the tissue within hours (51). Thus, it has been suggested that $\mathrm{T}_{\mathrm{RM}}$ function as an antigen-specific sensor and rapidly respond by producing signals that induce local inflammation and recruit memory $\mathrm{T}$ cells from the blood. Though it is not yet clear whether $\mathrm{T}_{\mathrm{RM}}$ in different tissues behave the same way, it will be important to determine what signals are released by $\mathrm{T}_{\mathrm{RM}}$ in response to stimulation and the effects that these have on the subsequent response. For example, we found that $\mathrm{T}_{\mathrm{RM}}$ express high levels of the chemokine XCL1, which may allow them to recruit $\mathrm{XCR} 1^{+}$cells such as dermal CD103 ${ }^{+}$DC (52) and facilitate local recall responses.

In addition to an alarm function, $\mathrm{T}_{\mathrm{RM}}$ presumably also contribute directly to the clearance of pathogens in tissues. Whether they do this via the killing of target cells or production or cytokines, or both, has not yet been determined. Moreover, the relative contribution of $\mathrm{T}_{\mathrm{RM}}$ versus memory $\mathrm{T}$ cells recruited from the circulation is not known. Thus, examination of whether skin $\mathrm{T}_{\mathrm{RM}}$ have the capacity to eradicate a local infection without the assistance of circulating memory $\mathrm{CD}^{+} \mathrm{T}$ cells will provide insight into the role of resident memory in protective immunity. The relative roles of $\mathrm{T}_{\mathrm{RM}}$ in raising the alarm versus directly clearing an infection may be influenced by their density with the tissue. We would predict that a high local density of $\mathrm{T}_{\mathrm{RM}}$ could protect against viral infection and possibly provide sterile immunity. There is some evidence to suggest that $\mathrm{T}_{\mathrm{RM}}$ also proliferate locally in response to challenge $(53,54)$, although the extent and widespread nature of this proliferation remains far from clear. Finally, given the restricted localization of $\mathrm{T}_{\mathrm{RM}}$ to epithelial layers such as the skin epidermis, we might predict that these memory cells are terminally differentiated and highly dependent on their environment to survive. Experiments suggest this is the case, since isolation of $\mathrm{T}_{\mathrm{RM}}$ from the brain followed by adoptive transfer into mice demonstrated poor survival and responses to challenge (33). Nevertheless, it remains unclear whether $\mathrm{T}_{\mathrm{RM}}$ can exit the epithelial layers upon recall and migrate through tissues or enter the circulation, and if they do whether they can survive. Finally, experiments are needed to determine if $\mathrm{T}_{\mathrm{RM}}$ form secondary memory in the tissues following restimulation, or are replaced by memory cells recruited from the circulation.

\section{PERSPECTIVES}

There is considerable complexity in the immune cell content of the skin. While this content includes populations such as $\mathrm{T}$ cells and DCs, it is now clear that these are heterogeneous, comprised of a number of phenotypically and functionally distinct subsets. In the case of T cells in particular, their action is predominantly local, affording regional protection against skin-invading pathogens or promoting tissue repair after injury. Given the need for such restricted action, it is not surprising that the skin contains skin-resident populations. Despite this, the relative contribution of resident versus migrating cells still remains unclear in many instances. The existence of such uncertainty highlights the need for clear demarcation between resident and migrating populations in future studies of the skin immune system.

\section{REFERENCES}

1. Grice EA, Segre JA. The skin microbiome. Nat Rev Microbiol (2011) 9:244-53. doi:10.1038/nrmicro2537

2. Solanas G, Benitah SA. Regenerating the skin: a task for the heterogeneous stem cell pool and surrounding niche. Nat Rev Mol Cell Biol (2013) 14:737-48. doi:10.1038/nrm3675

3. Wang X-N, McGovern N, Gunawan M, Richardson C, Windebank M, Siah T-W, et al. A three-dimensional atlas of human dermal leukocytes, lymphatics, and blood vessels. J Invest Dermatol (2014) 134:965-74. doi:10.1038/jid.2013.481

4. Heath WR, Carbone FR. The skin-resident and migratory immune system in steady state and memory: innate lymphocytes, dendritic cells and T cells. Nat Immunol (2013) 14:978-85. doi:10.1038/ni.2680

5. Allan RS, Waithman J, Bedoui S, Jones CM, Villadangos JA, Zhan Y, et al. Migratory dendritic cells transfer antigen to a lymph node-resident dendritic cell population for efficient CTL priming. Immunity (2006) 25:153-62. doi:10.1016/j.immuni.2006.04.017

6. Shklovskaya E, O’Sullivan BJ, Ng LG, Roediger B, Thomas R, Weninger W, et al. Langerhans cells are precommitted to immune tolerance induction. Proc Natl Acad Sci U S A (2011) 108:18049-54. doi:10.1073/pnas.1110076108

7. Seneschal J, Clark RA, Gehad A, Baecher-Allan CM, Kupper TS. Human epidermal Langerhans cells maintain immune homeostasis in skin by activating skin resident regulatory T cells. Immunity (2012) 36:873-84. doi:10.1016/j.immuni. 2012.03.018

8. Igyártó BZ, Haley K, Ortner D, Bobr A, Gerami-Nejad M, Edelson BT, et al. Skin-resident murine dendritic cell subsets promote distinct and opposing antigen-specific t helper cell responses. Immunity (2011) 35(2):260-72. doi:10.1016/j.immuni.2011.06.005

9. Allan RS, Smith CM, Belz GT, van Lint AL, Wakim LM, Heath WR, et al. Epidermal viral immunity induced by CD8alpha+ dendritic cells but not by Langerhans cells. Science (2003) 301:1925-8. doi:10.1126/science.1087576

10. Bedoui S, Whitney PG, Waithman J, Eidsmo L, Wakim L, Caminschi I, et al. Cross-presentation of viral and self antigens by skin-derived CD103+ dendritic cells. Nat Immunol (2009) 10:488-95. doi:10.1038/ni.1724

11. Abtin A, Jain R, Mitchell AJ, Roediger B, Brzoska AJ, Tikoo S, et al. Perivascular macrophages mediate neutrophil recruitment during bacterial skin infection. Nat Immunol (2014) 15:45-53. doi:10.1038/ni.2769

12. Luci C, Reynders A, Ivanov II, Cognet C, Chiche L, Chasson L, et al. Influence of the transcription factor RORgammat on the development of NKp46+ cell populations in gut and skin. Nat Immunol (2009) 10:75-82. doi:10.1038/ni.1681

13. Roediger B, Kyle R, Yip KH, Sumaria N, Guy TV, Kim BS, et al. Cutaneous immunosurveillance and regulation of inflammation by group 2 innate lymphoid cells. Nat Immunol (2013) 14(6):564-73. doi:10.1038/ni.2584

14. Villanova F, Flutter B, Tosi I, Grys K, Sreeneebus H, Perera GK, et al. Characterization of innate lymphoid cells in human skin and blood demonstrates increase of NKp44+ ILC3 in psoriasis. J Invest Dermatol (2014) 134:984-91. doi:10.1038/jid.2013.477

15. Clark RA, Chong B, Mirchandani N, Brinster NK, Yamanaka K-I, Dowgiert RK, et al. The vast majority of CLA+ T cells are resident in normal skin. J Immunol (2006) 176:4431-9. doi:10.4049/jimmunol.176.7.4431

16. Naik S, Bouladoux N, Wilhelm C, Molloy MJ, Salcedo R, Kastenmuller W, et al. Compartmentalized control of skin immunity by resident commensals. Science (2012) 337:1115-9. doi:10.1126/science.1225152

17. Chow Z, Mueller SN, Deane JA, Hickey MJ. Dermal regulatory T cells display distinct migratory behavior that is modulated during adaptive and innate inflammation. J Immunol (2013) 191:3049-56. doi:10.4049/jimmunol.1203205

18. Gebhardt T, Whitney PG, Zaid A, Mackay LK, Brooks AG, Heath WR, et al. Different patterns of peripheral migration by memory CD4+ and CD8+ T cells. Nature (2011) 477:216-9. doi:10.1038/nature10339

19. Gebhardt T, Wakim L, Eidsmo L, Reading P, Heath W, Carbone F. Memory $\mathrm{T}$ cells in nonlymphoid tissue that provide enhanced local immunity during infection with herpes simplex virus. Nat Immunol (2009) 10(5):524-30. doi:10.1038/ni.1718

20. Sumaria N, Roediger B, Ng LG, Qin J, Pinto R, Cavanagh LL, et al. Cutaneous immunosurveillance by self-renewing dermal \{gamma\}\{delta\} T cells. J Exp Med (2011) 208:505-18. doi:10.1084/jem.20101824

21. Toulon A, Breton L, Taylor KR, Tenenhaus M, Bhavsar D, Lanigan C, et al. A role for human skin-resident T cells in wound healing. J Exp Med (2009) 206:743-50. doi:10.1084/jem.20081787 
22. Vantourout P, Hayday A. Six-of-the-best: unique contributions of $\gamma \delta$ T cells to immunology. Nat Rev Immunol (2013) 13:88-100. doi:10.1038/nri3384

23. Chodaczek G, Papanna V, Zal MA, Zal T. Body-barrier surveillance by epidermal $\gamma \delta$ TCRs. Nat Immunol (2012) 13:272-82. doi:10.1038/ni.2240

24. Komori HK, Witherden DA, Kelly R, Sendaydiego K, Jameson JM, Teyton L, et al. Cutting edge: dendritic epidermal $\gamma \delta \mathrm{T}$ cell ligands are rapidly and locally expressed by keratinocytes following cutaneous wounding. J Immunol (2012) 188:2972-6. doi:10.4049/jimmunol.1100887

25. Witherden DA, Verdino P, Rieder SE, Garijo O, Mills RE, Teyton L, et al. The junctional adhesion molecule JAML is a costimulatory receptor for epithelial gammadelta T cell activation. Science (2010) 329:1205-10. doi:10.1126/science. 1192698

26. Jameson J, Ugarte K, Chen N, Yachi P, Fuchs E, Boismenu R, et al. A role for skin gammadelta $\mathrm{T}$ cells in wound repair. Science (2002) 296:747-9. doi:10.1126/science.1069639

27. Puttur FK, Fernandez MA, White R, Roediger B, Cunningham AL, Weninger W, et al. Herpes simplex virus infects skin \{gamma\}\{delta\} T cells before Langerhans cells and impedes migration of infected Langerhans cells by inducing apoptosis and blocking E-cadherin downregulation. J Immunol (2010) 185(1):477-87. doi:10.4049/jimmunol.0904106

28. Jiang X, Clark RA, Liu L, Wagers AJ, Fuhlbrigge RC, Kupper TS. Skin infection generates non-migratory memory CD8+ T(RM) cells providing global skin immunity. Nature (2012) 483:227-31. doi:10.1038/nature10851

29. Masopust D, Choo D, Vezys V, Wherry EJ, Duraiswamy J, Akondy R, et al. Dynamic T cell migration program provides resident memory within intestinal epithelium. J Exp Med (2010) 207:553-64. doi:10.1084/jem.20090858

30. Zhang N, Bevan MJ. Transforming growth factor- $\beta$ signaling controls the formation and maintenance of gut-resident memory $\mathrm{T}$ cells by regulating migration and retention. Immunity (2013) 39:687-96. doi:10.1016/j.immuni.2013.08.019

31. Shin H, Iwasaki A. A vaccine strategy that protects against genital herpes by establishing local memory T cells. Nature (2012) 491:463-7. doi:10.1038/nature11522

32. Casey KA, Fraser KA, Schenkel JM, Moran A, Abt MC, Beura LK, et al. Antigenindependent differentiation and maintenance of effector-like resident memory $\mathrm{T}$ cells in tissues. J Immunol (2012) 188(10):4866-75. doi:10.4049/jimmunol. 1200402

33. Wakim LM, Woodward-Davis A, Bevan MJ. Memory T cells persisting within the brain after local infection show functional adaptations to their tissue of residence. Proc Natl Acad Sci U S A (2010) 107:17872-9. doi:10.1073/pnas. 1010201107

34. Anderson KG, Sung H, Skon CN, Lefrançois L, Deisinger A, Vezys V, et al. Cutting edge: intravascular staining redefines lung CD8 T cell responses. J Immunol (2012) 189:2702-6. doi:10.4049/jimmunol.1201682

35. Hofmann M, Pircher H. E-cadherin promotes accumulation of a unique memory CD8 T-cell population in murine salivary glands. Proc Natl Acad Sci U S A (2011) 108:16741-6. doi:10.1073/pnas.1107200108

36. Hofmann M, Oschowitzer A, Kurzhals SR, Krüger CC, Pircher H. Thymusresident memory CD8+ T cells mediate local immunity. Eur J Immunol (2013) 43:2295-304. doi:10.1002/eji.201343519

37. Schenkel JM, Fraser KA, Masopust D. Cutting edge: resident memory CD8 T cells occupy frontline niches in secondary lymphoid organs. J Immunol (2014) 192:2961-4. doi:10.4049/jimmunol.1400003

38. Mackay LK, Rahimpour A, Ma JZ, Collins N, Stock AT, Hafon M-L, et al. The developmental pathway for CD103(+)CD8(+) tissue-resident memory T cells of skin. Nat Immunol (2013) 14(12):1294-301. doi:10.1038/ni.2744

39. Teijaro JR, Turner D, Pham Q, Wherry EJ, Lefrançois L, Farber DL. Cutting edge: tissue-retentive lung memory CD4 T cells mediate optimal protection to respiratory virus infection. J Immunol (2011) 187:5510-4. doi:10.4049/jimmunol. 1102243

40. Skon CN, Lee J-Y, Anderson KG, Masopust D, Hogquist KA, Jameson SC. Transcriptional downregulation of S1pr1 is required for the establishment of resident memory CD8(+) T cells. Nat Immunol (2013) 14(12):1285-93. doi:10.1038/ni.2745
41. Gibbons DL, Abeler-Dorner L, Raine T, Hwang IY, Jandke A, Wencker M, et al. Cutting edge: regulator of $\mathrm{G}$ protein signaling-1 selectively regulates gut $\mathrm{T}$ cell trafficking and colitic potential. J Immunol (2011) 187:2067-71. doi:10.4049/jimmunol.1100833

42. Zaid A, Mackay LK, Rahimpour A, Braun A, Veldhoen M, Carbone FR, et al. Persistence of skin-resident memory T cells within an epidermal niche. Proc Natl Acad Sci U S A (2014) 111:5307-12. doi:10.1073/pnas.1322292111

43. Zhu J, Koelle DM, Hladik F, Wald A, Corey L. Virus-specific CD8+ T cells accumulate near sensory nerve endings in genital skin during subclinical HSV-2 reactivation. J Exp Med (2007) 204:595-603. doi:10.1084/jem.20061792

44. Cheuk S, Wikén M, Blomqvist L, Nylén S, Talme T, Ståhle M, et al. Epidermal th22 and tc17 cells form a localized disease memory in clinically healed psoriasis. J Immunol (2014) 192:3111-20. doi:10.4049/jimmunol.1302313

45. Ariotti S, Beltman JB, Chodaczek G, Hoekstra ME, van Beek AE, Gomez-Eerland $\mathrm{R}$, et al. Tissue-resident memory CD8+ T cells continuously patrol skin epithelia to quickly recognize local antigen. Proc Natl Acad Sci U S A (2012) 109:19739-44. doi:10.1073/pnas.1208927109

46. Lämmermann T, Sixt M. Mechanical modes of 'amoeboid' cell migration. Curr Opin Cell Biol (2009) 21:636-44. doi:10.1016/j.ceb.2009.05.003

47. McCully ML, Ladell K, Hakobyan S, Mansel RE, Price DA, Moser B. Epidermis instructs skin homing receptor expression in human T cells. Blood (2012) 120:4591-8. doi:10.1182/blood-2012-05-433037

48. De Creus A, Van Beneden K, Stevenaert F, Debacker V, Plum J, Leclercq G. Developmental and functional defects of thymic and epidermal $\mathrm{V}$ gamma 3 cells in IL-15-deficient and IFN regulatory factor-1-deficient mice. J Immunol (2002) 168:6486-93. doi:10.4049/jimmunol.168.12.6486

49. Kadow S, Jux B, Zahner SP, Wingerath B, Chmill S, Clausen BE, et al. Aryl hydrocarbon receptor is critical for homeostasis of invariant gammadelta $\mathrm{T}$ cells in the murine epidermis. J Immunol (2011) 187:3104-10. doi:10.4049/jimmunol. 1100912

50. Esser C, Bargen I, Weighardt H, Haarmann-Stemmann T, Krutmann J. Functions of the aryl hydrocarbon receptor in the skin. Semin Immunopathol (2013) 35:677-91. doi:10.1007/s00281-013-0394-4

51. Schenkel JM, Fraser KA, Vezys V, Masopust D. Sensing and alarm function of resident memory CD8(+) T cells. Nat Immunol (2013) 14(5):509-13. doi:10.1038/ni.2568

52. Yamazaki C, Sugiyama M, Ohta T, Hemmi H, Hamada E, Sasaki I, et al. Critical roles of a dendritic cell subset expressing a chemokine receptor, XCR1. J Immunol (2013) 190:6071-82. doi:10.4049/jimmunol.1202798

53. Wakim LM, Waithman J, van Rooijen N, Heath WR, Carbone FR. Dendritic cell-induced memory T cell activation in nonlymphoid tissues. Science (2008) 319:198-202. doi:10.1126/science.1151869

54. Cuburu N, Graham BS, Buck CB, Kines RC, Pang Y-YS, Day PM, et al. Intravaginal immunization with HPV vectors induces tissue-resident CD8+ T cell responses. J Clin Invest (2012) 122:4606-20. doi:10.1172/JCI63287

Conflict of Interest Statement: The authors declare that the research was conducted in the absence of any commercial or financial relationships that could be construed as a potential conflict of interest.

Received: 28 May 2014; accepted: 30 June 2014; published online: 16 July 2014. Citation: Mueller SN, Zaid A and Carbone FR (2014) Tissue-resident T cells: dynamic players in skin immunity. Front. Immunol. 5:332. doi: 10.3389/fimmu.2014.00332 This article was submitted to Immunological Memory, a section of the journal Frontiers in Immunology.

Copyright $($ C 2014 Mueller, Zaid and Carbone. This is an open-access article distributed under the terms of the Creative Commons Attribution License (CC BY). The use, distribution or reproduction in other forums is permitted, provided the original author(s) or licensor are credited and that the original publication in this journal is cited, in accordance with accepted academic practice. No use, distribution or reproduction is permitted which does not comply with these terms. 